Article

\title{
Conservation Benefits of Tropical Multifunctional Land-Uses in and Around a Forest Protected Area of Bangladesh ${ }^{\dagger}$
}

\author{
Sharif A. Mukul ${ }^{1,2,3, *}$ and Narayan Saha ${ }^{4}$ \\ 1 Tropical Forestry Group, School of Agriculture and Food Sciences, The University of Queensland, \\ Brisbane QLD 4072, Australia \\ 2 Tropical Forests and People Research Centre, University of the Sunshine Coast, \\ Maroochydore QLD 4558, Australia \\ 3 Centre for Research on Land-use Sustainability, Noakhali 3800, Bangladesh \\ 4 Department of Forestry and Environmental Science, School of Agriculture and Mineral Sciences, \\ Shahjalal University of Science and Technology, Sylhet 3114, Bangladesh; nsaha12010-fes@sust.edu \\ * Correspondence: s.mukul@uq.edu.au or sharif_a_mukul@yahoo.com; Tel.: +61-041-6648-544 \\ + This paper is extended from the version presented at the 23rd IUFRO World Congress (Forests for the Future: \\ Sustaining Society and the Environment) held in Seoul, Republic of Korea during 23-28 August 2010.
}

Academic Editors: Jeffrey Sayer and Chris Margules

Received: 16 November 2016; Accepted: 26 December 2016; Published: 1 January 2017

\begin{abstract}
Competing interests in land for agriculture and commodity production in tropical human-dominated landscapes make forests and biodiversity conservation particularly challenging. Establishment of protected areas in this regard is not functioning as expected due to exclusive ecological focus and poor recognition of local people's traditional forest use and dependence. In recent years, multifunctional land-use systems such as agroforestry have widely been promoted as an efficient land-use in such circumstances, although their conservation effectiveness remains poorly investigated. We undertake a rapid biodiversity survey to understand the conservation value of four contrasting forms of local land-use, namely: betel leaf (Piper betle) agroforestry; lemon (Citrus limon) agroforestry; pineapple (Ananas comosus) agroforestry; and, shifting cultivation-fallow managed largely by the indigenous communities in and around a highly diverse forest protected area of Bangladesh. We measure the alpha and beta diversity of plants, birds, and mammals in these multifunctional land-uses, as well as in the old-growth secondary forest in the area. Our study finds local land-use critical in conserving biodiversity in the area, with comparable biodiversity benefits as those of the old-growth secondary forest. In Bangladesh, where population pressure and rural people's dependence on forests are common, multifunctional land-uses in areas of high conservation priority could potentially be used to bridge the gap between conservation and commodity production, ensuring that the ecological integrity of such landscapes will be altered as little as possible.
\end{abstract}

Keywords: biodiversity conservation; agroforestry; traditional land-use; land-sparing; land-sharing; wildlife

\section{Introduction}

The vast majority of tropical forests have either been transformed or degraded by human activity, with agricultural expansion being widely recognised as the major driver of this change $[1,2]$. In the tropics, the ever-growing demand for land to accommodate production systems, while conserving biodiversity, providing ecosystem services, and maintaining rural people's livelihoods, make land management particularly challenging [3-6]. As forest loss and degradation continue to rise in most parts of the tropics, the international community is faced with the challenge of finding strategies that are convenient to both rural livelihoods and biodiversity conservation $[7,8]$. Land-sparing (setting aside 
land for conservation and agriculture separately) and land-sharing (integrated approach that makes land-use more conducive to biodiversity conservation) have emerged in recent years as contrasting strategies to tackle the trade-offs between livelihoods and biodiversity conservation [9]. Although the establishment of protected areas has widely been viewed as the most effective strategy to conserve biodiversity, many forest protected areas in the developing tropics are isolated and situated in a complex mosaic of agricultural land-use with high dependency of local people on them, reducing their capacity to maintain the biological diversity that they were originally designated to protect $[10,11]$.

Agroforestry is a multifunctional land-use that involves integration of agricultural and forestry production systems in the same unit of land [8]. In the tropics, agroforestry has widely been promoted for the conservation of biodiversity with support for rural livelihoods [12]. The coffee, cacao, or the jungle rubber agroforestry systems are a few of the examples, although rapid intensification to increase crop yields and productivity make their role questionable in some regions [12,13]. Conservation biologists are also devoting an increasing amount of energy to exploring whether these multifunctional land-use systems are favourable for biodiversity conservation at both local and global scales.

Being situated in a tropical monsoon climate, Bangladesh is exceptionally rich in biodiversity [14]. Many agroforestry systems are common in the country and are managed by local and indigenous communities $[15,16]$. However, as with other tropical countries, intensified management of local agroforestry systems due to high demand for food and other products that has been further exacerbated by market forces and rapid agricultural development makes their role in conservation debatable [17]. Few studies, however, have so far been conducted in different parts of the country with respect to various aspects of agroforestry (e.g., [18-22]); their conservation benefit and/or ability to complement the forests have rarely been evaluated. Our study thus aimed to explore whether the multifunctional agroforestry land-use in the country is capable of biodiversity conservation (objective 1), and if it can complement the old-growth and/or less-disturbed forests (objective 2). We performed the study in a northeastern protected area of the country marked by diverse plants and wildlife. Our study is useful to understand the role of multifunctional agroforestry land-use in conservation of biodiversity in tropical human-dominated landscapes.

\section{Study Area}

We conducted our study in and around Lawachara National Park (LNP), one of the richest forest patches in Bangladesh (Figure 1). Several indigenous communities also live in and adjacent to the park and are dependent on it for sustaining their livelihood [16]. Geographically, the park is located between $24^{\circ} 30^{\prime}-24^{\circ} 32^{\prime} \mathrm{N}$ latitude and $91^{\circ} 37^{\prime}-91^{\circ} 39^{\prime} \mathrm{E}$ longitude with an area of about 1250 hectares. The topography of the area is undulating, with slopes and hillocks ranging from 10 to $50 \mathrm{~m}$ in elevation [23]. The forest of the park area originally supported tropical semi-evergreen to wet evergreen forests [24]. Presently, the area is surrounded by a complex mosaic of landscapes, dominated by tea (Camellia sinensis) and rubber (Hevea brasiliensis) gardens, plantations of commercially valuable timber species, bamboo and rattan plantations, and agricultural fields [25]. The area also experiences one of the highest rainfalls ( $\sim 4000 \mathrm{~mm} /$ year) in the country due to its geographic location [26].

In LNP, most of the primary forest has been removed or substantially altered, with some plantations that were established in the area between 1920 and 1950 having now become part of the original forest cover and considered as old-growth secondary forest [25]. Approximately 130 ha of forest area have been used for betel leaf (Piper betle) cultivation within the park area, primarily by the indigenous Khasia community [16]. The main crop is betel leaf, a perennial dioecious climber that creeps up forest trees using its adventitious roots. This vine grows well in moist forest conditions with high humidity and soil moisture. Other forms of land-use, such as lemon agroforestry and pineapple agroforestry, are practiced mostly by the indigenous Tripura community and are common within and on the periphery of the park. Both lemon and pineapple agroforestry land-use require intensive management by the farmers, where they retain some of the forest tree species and cultivate few fruit species (e.g., Jackfruit; Artocarpus heterophyllus) with the main crop lemon in the lemon agroforestry 
land-use. In pineapple agroforestry land-use, farmers usually retain tree species that are tall enough or with very little branch to allow maximum sunlight to the main crop pineapple. Removal of weeds and application of chemical and organic fertilisers are also common management practices in both agroforestry land-uses.

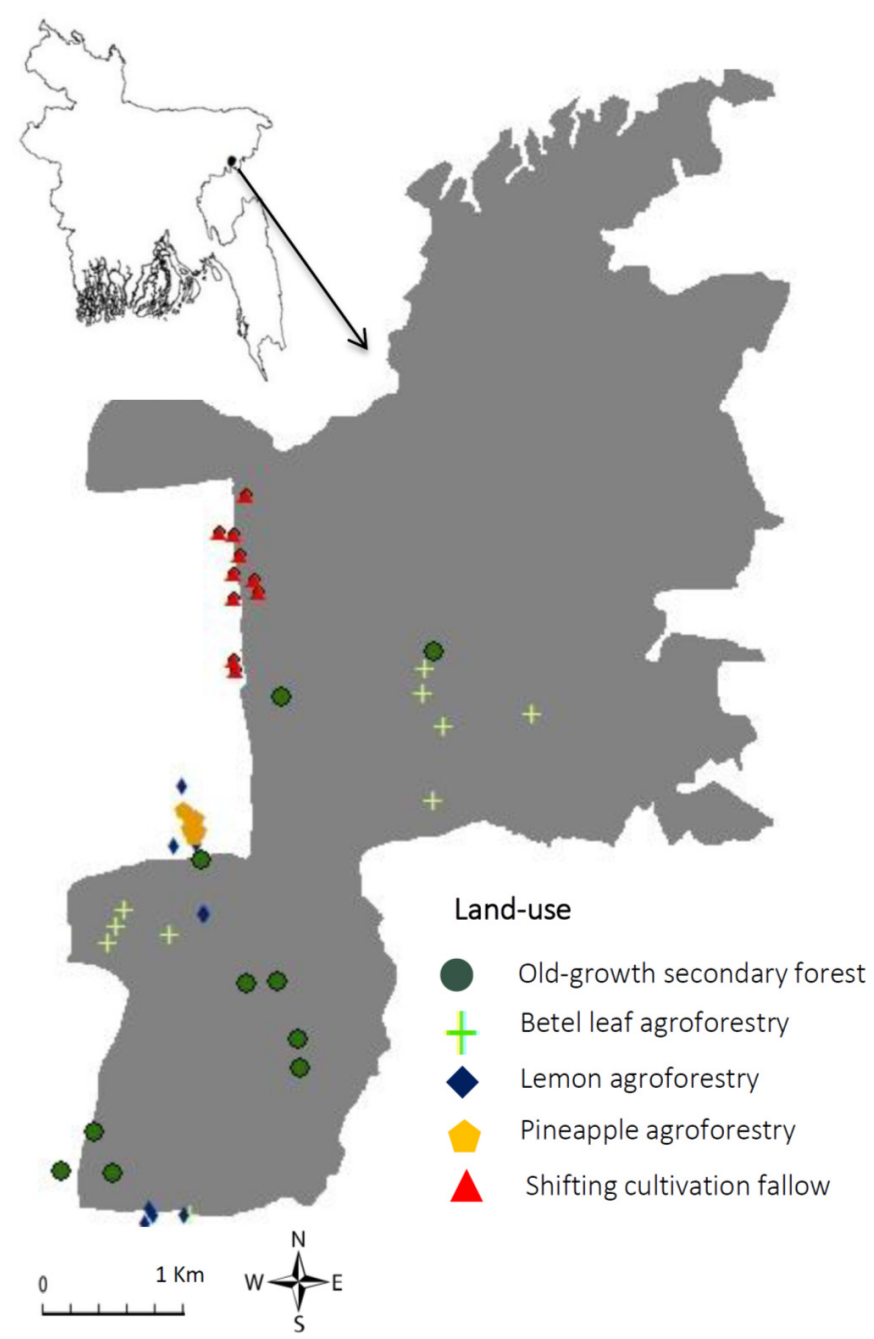

Figure 1. Map of the study area with location of the study plots used for vegetation survey in and around Lawachara National Park (LNP), Bangladesh.

While shifting cultivation is not a common form of land-use in the area, slashing and burning of an old teak plantation administered by the Forest Department and short-term agricultural use of the cleared area by the indigenous Garo people gave us the opportunity to study this traditional land-use common in most of the tropics [27]. We, however, acknowledge that it may not properly reflect the ideal state of shifting cultivation-fallow common in the tropics. Figure 2 shows the common land-uses in and around Lawachara National Park, Bangladesh. 


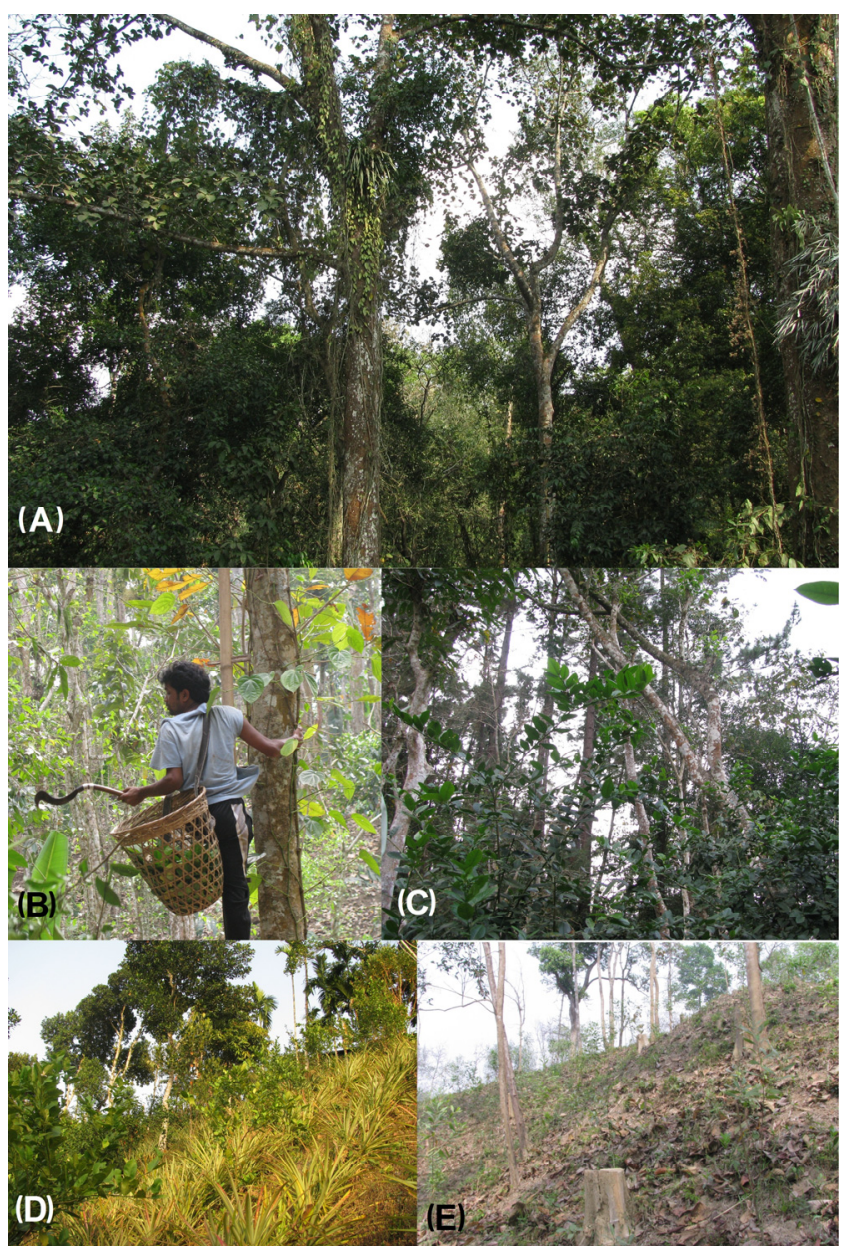

Figure 2. Different land-uses in and around Lawachara National Park-(A) Old-growth secondary forest; (B) Betel leaf agroforestry; (C) Lemon agroforestry; (D) Pineapple agroforestry; and (E) Shifting cultivation-fallow (Photo credits: Sharif A. Mukul).

\section{Data Collection}

Biodiversity assessment was undertaken during 2009 through a series of field surveys in the area. We recorded abundance and richness of trees, birds and mammals during the time of the survey. For the vegetation survey, a total of 50,100 $\mathrm{m}^{2}$ randomly selected plots were established, representing four multifunctional agroforestry land-uses and the old-growth secondary forest (Figure 1). Within each $10 \mathrm{~m} \times 10 \mathrm{~m}$ rectangular plot, we identified all mature trees $\geq 5 \mathrm{~cm}$ at diameter at breast height (dbh). Tree species were identified in the field and were cross-checked using available references [28,29]. For bird diversity, we used 25 points ( 5 land-use $\times 5$ replicate) with a $25 \mathrm{~m}$ radius for a period of one hour. In each point, observations were made from a suitable place during daylight hours with periodic movements within the area to detect and identify available cryptic and non-vocal species. Nocturnal birds were excluded from this survey. For mammalian diversity, we organized a walk along 25 pre-established trails (5 land-use $\times 5$ replicate) at a very slow pace $(\sim 2 \mathrm{~km} / \mathrm{h})$, as done by Carrillo et al. [30]. All walks were performed early in the morning and/or late in the afternoon.

\section{Data Analysis}

We measured alpha $(\alpha)$ and beta $(\beta)$ diversity of trees, birds and mammals in the studied land-use both at the plot and landscape levels. Species abundance, richness and the Shannon-Wiener index $(H)$ were used as measures of alpha diversity, while we used Jaccard's similarity matrix $(I)$ and ordination 
using non-metric multi-dimensional scaling (NMDS) to determine the beta diversity of species across contrasting land-uses and plots.

Species abundance was defined as the number of individuals found in a land-use/plot. Species richness was defined as the number of unique species per land-use/plot. The Shannon-Wiener index was calculated using the equation below [31].

$$
H=-\sum p_{i} \ln p_{i}
$$

where $H$ is the Shannon-Wiener index, $p_{i}$ is the proportion of individuals found in the $i$-th species.

We used Bray-Curtis distance with 1000 iterations for non-metric multi-dimensional scaling using the species richness data at the plot level. Jaccard's similarity matrix was used to determine how similar or different the trees, birds or mammal species were between any pair of land-use types, and the measure was obtained using the following equation;

$$
I=s_{i j} /\left(s_{i}+s_{j}-s_{i j}\right)
$$

where $s_{i j}$ is the number of species found in land-use $i$ and $j, s_{i}$ is the species found in land-use $i$, and $s_{j}$ is the species found in land-use $j$. The estimate ranges between 0 and 1 , where the higher values indicate more similarities between two different land-uses in terms of species richness.

All statistical analysis was performed in the R Statistical environment [32]. We used the package "vegan" for diversity analysis. ANOVA (analysis of variance) and post-hoc analysis were performed to evaluate if there was any significant difference among means.

\section{Results}

\subsection{Does Multifunctional Agroforestry Land-Use Conserve Forest Biodiversity?}

During our biodiversity survey, altogether we found 44 species of trees, 53 bird species, and 19 mammal species from our sites in the Lawachara forest. Table 1 shows the number of trees, birds and mammals found at the landscape level from each land-use type in the area. Tree species richness was highest in the betel leaf agroforestry system, while bird and mammal species richness was highest in the old-growth forest. There were no mature trees in several sites devoted to pineapple agroforestry and shifting cultivation-fallow sites in the area. These numbers, however, do not necessarily reflect the actual biodiversity of the area in studied land-use, which can be also affected by sampling design, survey area, and survey time.

Table 1. Biodiversity of trees, birds and mammals in contrasting land-uses in and around Lawachara National Park, Bangladesh.

\begin{tabular}{cccc}
\hline \multirow{2}{*}{ Land-Use } & \multicolumn{3}{c}{ Biodiversity } \\
\cline { 2 - 4 } & Tree * & Bird & Mammal \\
\hline Old-growth secondary forest & $20(55)$ & $31(59)$ & $25(44)$ \\
Betel leaf agroforestry & $22(55)$ & $23(32)$ & $16(22)$ \\
Lemon agroforestry & $8(32)$ & $14(31)$ & $15(17)$ \\
Pineapple agroforestry & $11(10)$ & $9(18)$ & $7(9)$ \\
Shifting cultivation-fallow & $9(26)$ & $11(28)$ & $16(11)$ \\
\hline
\end{tabular}

* Values in the parenthesis indicate the abundance of species.

Figure 3 shows the biodiversity (richness and Shannon-Wiener index) of trees, birds and mammals in studied land-use types in and around Lawachara. Interestingly, both tree species abundance $(p<0.0$; $F=12.99)$, richness $(p<0.0 ; F=10.45)$ and the Shannon-Wiener index $(p<0.0 ; F=10.45)$ were significantly high in the betel leaf agroforestry system, followed by the old-growth secondary forest, lemon agroforestry, shifting cultivation-fallow and pineapple agroforestry systems. 


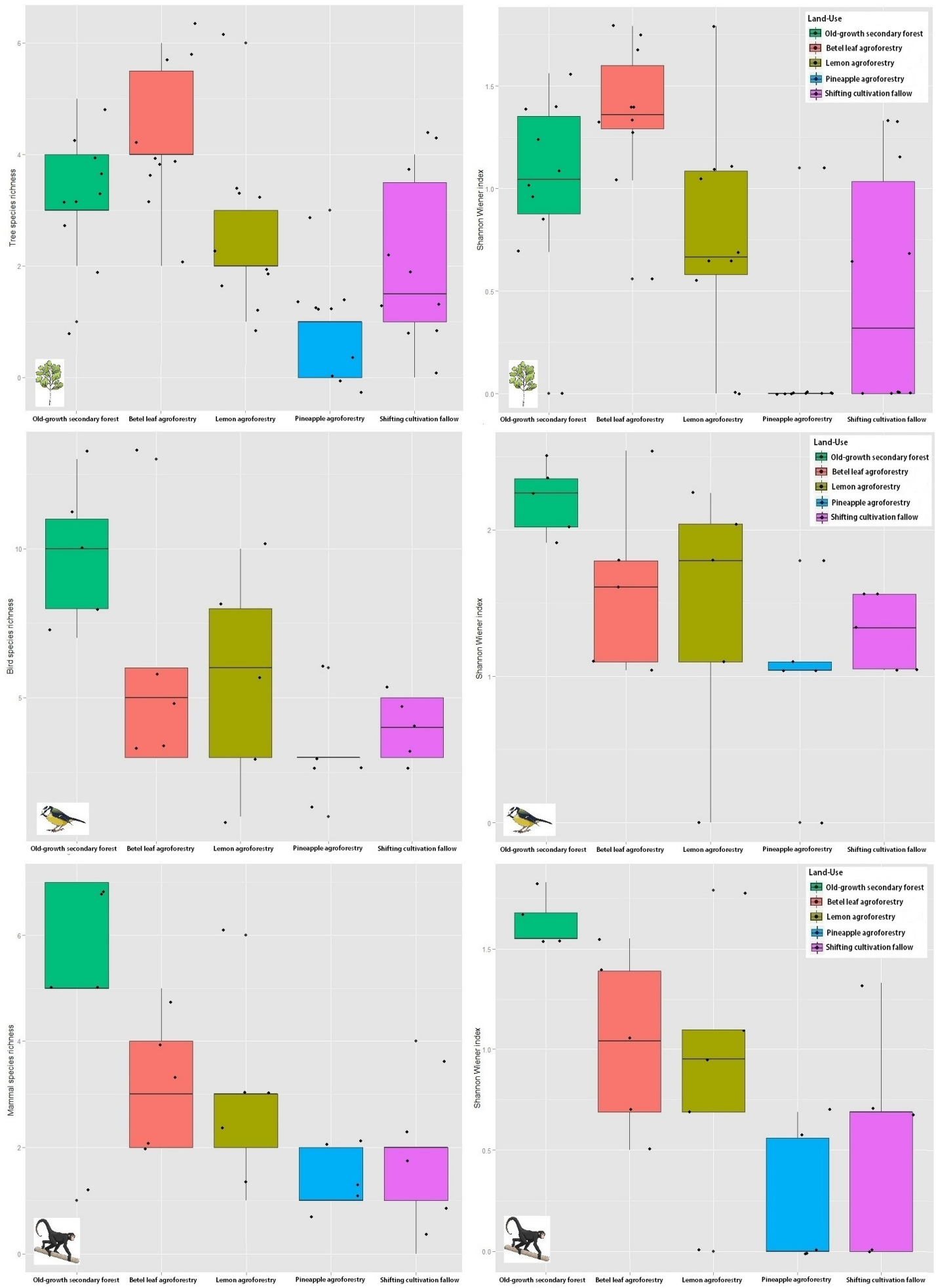

Figure 3. Biodiversity of trees, birds and mammals in contrasting land-uses in and around Lawachara National Park, Bangladesh.

Bird species abundance $(p<0.05 ; F=4.32)$, richness $(p<0.05 ; F=4.05)$, and the Shannon-Wiener index $(p<0.05 ; F=2.91)$ were however significantly high in the old-growth secondary forest, followed by betel leaf agroforestry, lemon agroforestry, shifting cultivation-fallow, and pineapple agroforestry. Mammal abundance $(p<0.01 ; F=4.97)$ and richness $(p<0.05 ; F=3.63)$ were significantly high in the 
old-growth secondary forests, while there were no significant differences in the Shannon-Wiener index $(p>0.05 ; F=2.73)$ across the land-uses.

\subsection{Can Tropical Multifunctional Land-Uses Complement the Less-Disturbed Forest?}

Tables 2-4 show the similarities of tree, bird and mammal species richness across the landscapes in different agroforestry land-uses as well as in the old-growth secondary forest in the Lawachara area using Jaccard's matrix of similarities. Interestingly, the old-growth secondary forest shared higher numbers of species with lemon agroforestry and shifting cultivation-fallow in the area than betel leaf agroforestry land-use. Betel leaf agroforestry land-use, however, had the highest number of common birds and mammals with the old-growth secondary forest than other land-uses in the area (see Tables 3 and 4).

Table 2. Similarity matrix of tree species across the studied land-uses in and around Lawachara.

\begin{tabular}{ccccc}
\hline Land-Use & $\begin{array}{c}\text { Betel Leaf } \\
\text { Agroforestry }\end{array}$ & $\begin{array}{c}\text { Lemon } \\
\text { Agroforestry }\end{array}$ & $\begin{array}{c}\text { Pineapple } \\
\text { Agroforestry }\end{array}$ & $\begin{array}{c}\text { Shifting } \\
\text { Cultivation-Fallow }\end{array}$ \\
\hline Old-growth secondary forest & 0.11 & 0.30 & 0.09 & 0.17 \\
Betel leaf agroforestry & & 0.24 & 0.13 & 0.11 \\
Lemon agroforestry & & & 0.26 & 0.13 \\
Pineapple agroforestry & & & & 0 \\
\hline
\end{tabular}

Table 3. Similarity matrix of bird species across the studied land-uses in and around Lawachara.

\begin{tabular}{ccccc}
\hline Land-Use & $\begin{array}{c}\text { Betel Leaf } \\
\text { Agroforestry }\end{array}$ & $\begin{array}{c}\text { Lemon } \\
\text { Agroforestry }\end{array}$ & $\begin{array}{c}\text { Pineapple } \\
\text { Agroforestry }\end{array}$ & $\begin{array}{c}\text { Shifting } \\
\text { Cultivation-Fallow }\end{array}$ \\
\hline Old-growth secondary forest & 0.29 & 0.16 & 0.08 & 0.14 \\
Betel leaf agroforestry & & 0.19 & 0.07 & 0.22 \\
Lemon agroforestry & & & 0.21 & 0.14 \\
Pineapple agroforestry & & & & 0.11 \\
\hline
\end{tabular}

Table 4. Similarity matrix of mammals across the studied land-uses in and around Lawachara.

\begin{tabular}{ccccc}
\hline Land-Use & $\begin{array}{c}\text { Betel Leaf } \\
\text { Agroforestry }\end{array}$ & $\begin{array}{c}\text { Lemon } \\
\text { Agroforestry }\end{array}$ & $\begin{array}{c}\text { Pineapple } \\
\text { Agroforestry }\end{array}$ & $\begin{array}{c}\text { Shifting } \\
\text { Cultivation-Fallow }\end{array}$ \\
\hline Old-growth secondary forest & 0.53 & 0.53 & 0.47 & 0.26 \\
Betel leaf agroforestry & & 0.47 & 0.64 & 0.46 \\
Lemon agroforestry & & & 0.50 & 0.46 \\
Pineapple agroforestry & & & & 0.36 \\
\hline
\end{tabular}

When looking at plot level similarities between different land-use in the area using non-metric multi-dimensional scaling and species richness, we observed greater overlaps of tree species between the old-growth secondary forest and lemon agroforestry. NMDS reveals overlaps of tree species with different land-uses and the old-growth secondary forest in the area (Stress $=14.0$ ). A heterogeneous bird species assemblage was found across the plots of different land-use (Stress $=20.58$ ), although a greater number of bird species was shared between betel leaf agroforestry and the old-growth secondary forest in the area. All agroforestry land-use types shared some mammal species with the old-growth secondary forest in the area, although we observed no visible pattern in mammal species assemblage in the area (Stress =17.75). Figures 4-6 show ordination of plots using species richness of mature trees, birds and mammals in the area, where scattered plots indicate a more heterogeneous species assemblage, and closer plots indicate a more homogenous species assemblage across plots of different land-use types. The axes here in the figures are arbitrary as is the orientation of the plot. 


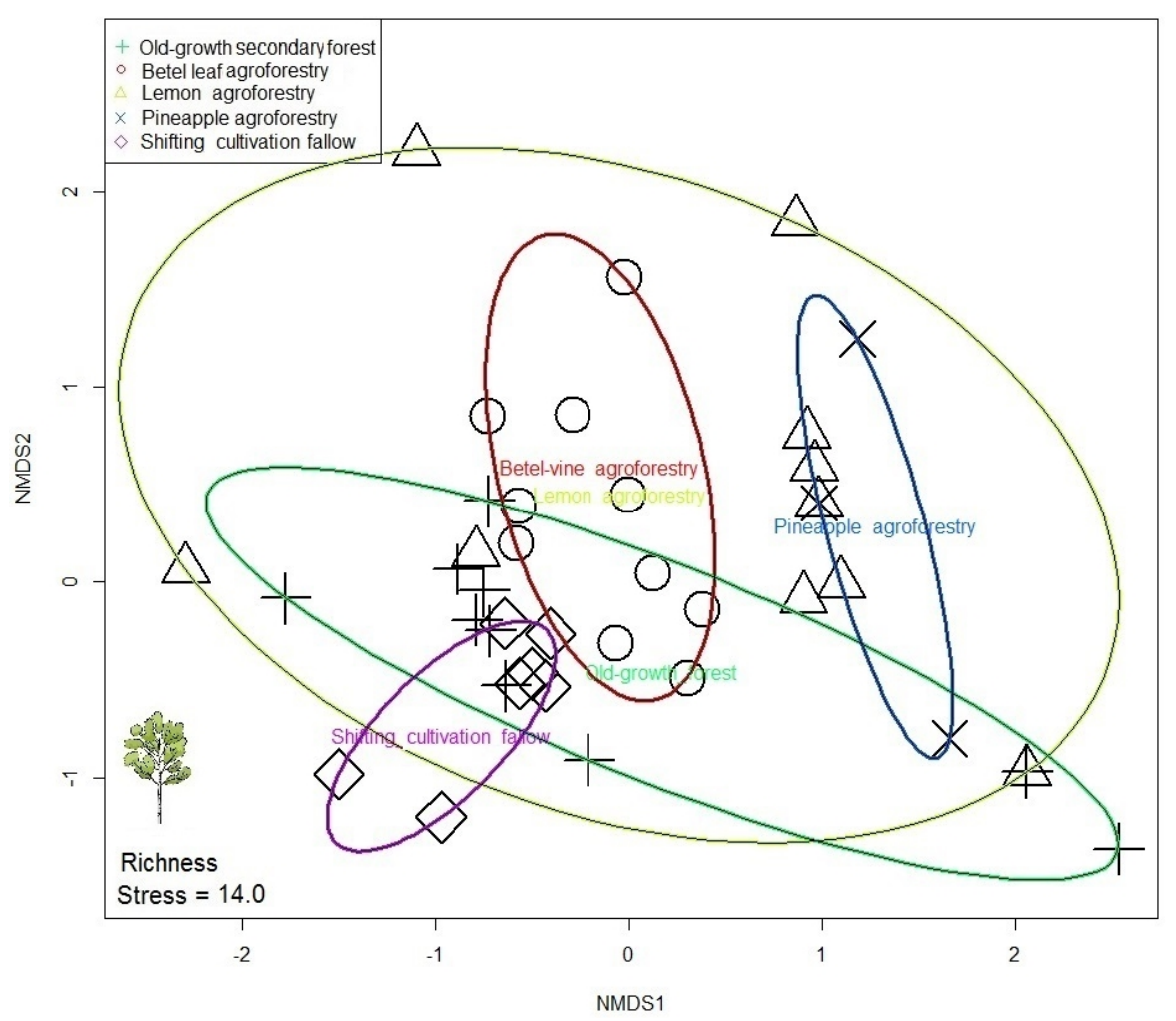

Figure 4. Ordination using non-metric multi-dimensional scaling and tree species richness.

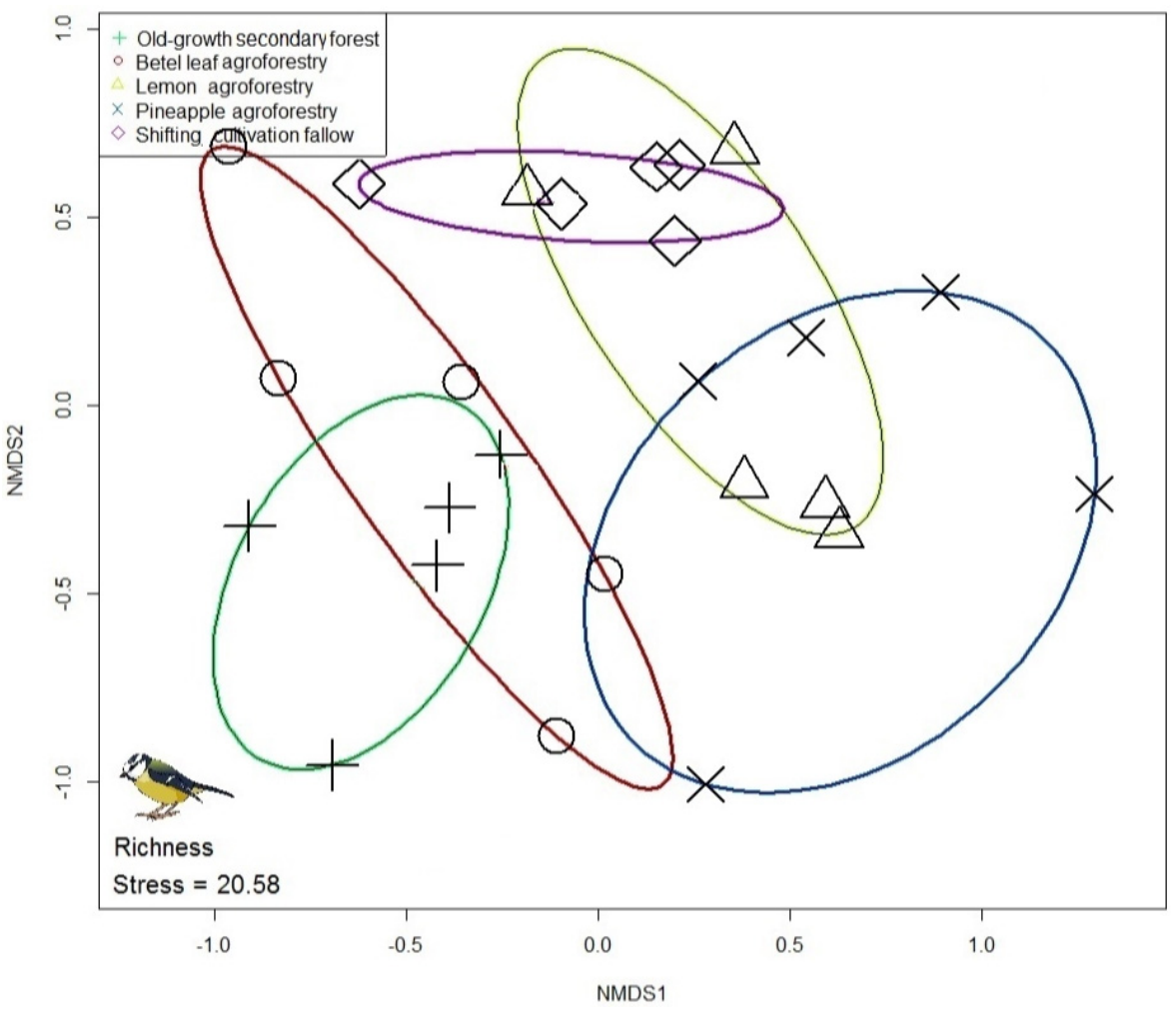

Figure 5. Ordination using non-metric multi-dimensional scaling and bird species richness. 


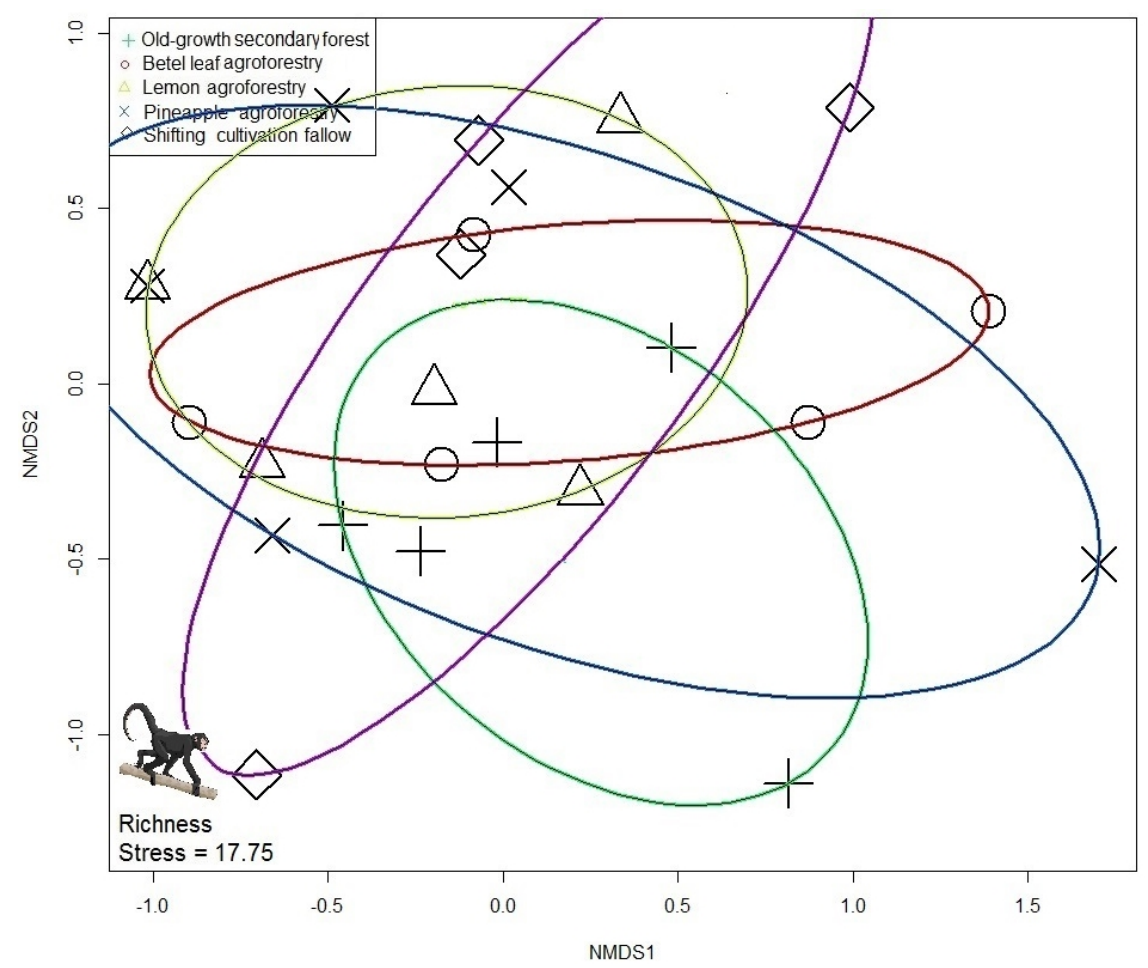

Figure 6. Ordination using non-metric multi-dimensional scaling and mammal species richness.

\section{Discussion and Conclusions}

We find tropical multifunctional agroforestry land-use suitable for biodiversity conservation in and around the Lawachara forest, although the ability of different land-use types to protect and conserve biodiversity was not similar. In our study, we observed a higher diversity of tree in betel leaf agroforestry, although bird and mammal diversity were higher in the old-growth secondary forest in the area. Compared to other land-use types, pineapple agroforestry, and shifting cultivation-fallow had a lower diversity of plants and mammals in the area. The betel leaf agroforestry land-use managed by the indigenous Khasia community provides superior conservation benefits in the area, which may be because it involved relatively less modification of natural vegetation compared to other land-uses [15]. Smallholder landowners here retain the native forest trees to use them as support for the betel leaf vine. The pineapple agroforestry system, on the other hand, involves the clearing of native vegetation to allow greater sunlight in land under use, with regular human intervention and the use of agrochemicals. Lemon agroforestry, although not as intensive as the pineapple agroforestry system, also involved more active management of the land for lemon production. When considering the ability of different multifunctional land-use types to complement the native vegetation of old-growth and/or less-disturbed secondary forests, we find betel leaf agroforestry also suitable for forest bird and mammal species, although lemon agroforestry shared a higher number of tree species with the old-growth secondary forest in the area than other agroforestry land-uses. We, however, did not include some other factors such as proximity to less-disturbed forest, the age of the land-use in our analysis, which may also influence the biodiversity in the studied land-use types [26]. For instance, the limited biodiversity in our shifting cultivation-fallow sites can be due to the relatively young age of the sites and/or recent history of disturbance. Tropical primary forests are believed to be irreplaceable for their unique biodiversity [33]. In human-dominated tropical forest landscapes, the increasing pressure on land for agriculture, however, makes their management complex [34]. In such a context, wildlife-friendly agriculture has been widely advocated to reduce the adverse effect of agriculture [35,36]. In many parts of the tropics, agroforestry land-uses have been common for centuries and making a contribution as a refuge for biodiversity conservation $[8,13,37]$. In recent years, 
rapid intensification of land-use with excessive use of agrochemicals and modification of land for higher yields has been unfavorably affecting the conservation value of such landscapes [17].

In Bangladesh, biodiversity conservation is challenging due to high population pressure, limited land designated for conservation, and high dependence of rural people on forests [25,38]. Conflicts between protected area managers and local peoples are common in the country due to limited access of local people to different income-generating options and poor recognition of their traditional ways of living [16,25]. In tropical multifunctional landscapes, there is a strong linkage between income and environmental benefits that sometime influence smallholders' motivation and preference for particular land-use(s) [39-41]. Earlier studies also suggest that, to some extent, higher protection status and local beliefs help to protect the declining biodiversity of the country $[26,42,43]$. The present study demonstrates that multifunctional land-uses such as agroforestry could potentially be used to protect and conserve biodiversity in the country, ensuring limited modification of the native vegetation and wildlife habitats. Such land-uses also hold great promise for integration in the available carbon forestry schemes, including reducing emissions from deforestation and forest degradation (REDD+) with benefits to both local livelihoods and the environment, although further studies are essential to quantify such benefits [44].

Acknowledgments: We would like to thank our respondents for sharing the information with us and Mashiur Rahman Tito, Mofizul Haque, Mohammad Abu Sayed Arfin Khan for accompanying during the study. The authors would like to acknowledge the infrastructure and other support provided by the Centre for Research on Land-use Sustainability, Bangladesh. The first author (SAM) was supported by the British Ecological Society (SEPG, UEPS Field Experience Grant 7210 600), British Ornithologist's Union (2009) and the Rufford Grant for Nature Conservation (RSG project 69.01.09). The authors greatly acknowledge the useful comments and suggestions from three anonymous reviewers.

Author Contributions: S.A.M. conceived the idea, conducted the field work and analysed the data; S.A.M. and N.S. wrote the paper.

Conflicts of Interest: The authors declare no conflicts of interest.

\section{References}

1. Uriarte, M.; Schneider, L.; Rudel, T.K. Land transitions in the tropics: Going beyond the case studies. Biotropica 2010, 42, 1-2. [CrossRef]

2. Sala, O.E.; Chapin, F.S.; Amesto, J.J. Global biodiversity scenarios for the year 2100. Science 2000, 287, 1770-1774. [CrossRef] [PubMed]

3. Law, E.A.; Bryan, B.A.; Meijaard, E.; Mallawaarachchi, T.; Struebig, M.J.; Watts, M.E.; Wilson, K.A. Mixed policies give more options in multifunctional tropical forest landscapes. J. Appl. Ecol. 2016. [CrossRef]

4. Mukul, S.A.; Herbohn, J.; Firn, J. Co-benefits of biodiversity and carbon sequestration from secondary forests in the Philippine uplands: Implications for forest landscape restoration. Biotropica 2016, 48, 882-889. [CrossRef]

5. Sayer, J.; Sunderland, T.; Ghazoul, J.; Pfund, J.L.; Sheil, D.; Meijaard, E.; Venter, M.; Boedhihartono, A.K.; Day, M.; Garcia, C. Ten principles for a landscape approach to reconciling agriculture, conservation, and other competing land uses. Proc. Natl. Acad. Sci. USA 2013, 110, 8349-8356. [CrossRef] [PubMed]

6. Harvey, C.A.; Gonzalez, J.A. Agroforestry systems conserve species-rich but modified assemblages of tropical birds and bats. Biodivers. Conserv. 2007, 16, 2257-2292. [CrossRef]

7. Santika, T.; Meijaard, E.; Wilson, K.A. Designing multifunctional landscapes for forest conservation. Environ. Res. Lett. 2015, 10, 114012. [CrossRef]

8. Bhagwat, S.A.; Willis, K.J.; Birks, H.J.B.; Whittaker, R.J. Agroforestry: A refuge for tropical biodiversity? Trends Ecol. Evolut. 2008, 23, 261-267. [CrossRef] [PubMed]

9. Kremen, C. Reframing the land-sparing/land-sharing debate for biodiversity conservation. Ann. N. Y. Acad. Sci. 2015, 1355, 52-76. [CrossRef] [PubMed]

10. Mukul, S.A.; Rashid, A.Z.M.M.; Uddin, M.B.; Khan, N.A. Role of non-timber forest products in sustaining forest-based livelihoods and rural households' resilience capacity in and around protected area: A Bangladesh study. J. Environ. Plan. Manag. 2016, 59, 628-642. [CrossRef] 
11. Nagendra, H. Do parks work? Impact of protected areas on land cover clearing. Ambio 2008, 37, 330-337. [CrossRef] [PubMed]

12. Schroth, G.; da Fonseca, G.A.B.; Harvey, C.A.; Gascon, C.; Vasconcelos, H.L.; Izac, A.N. (Eds.) Agroforestry and Biodiversity Conservation in Tropical Landscapes; Island Press: Washington, DC, USA, 2004.

13. Steffan-Dewenter, I.; Kessler, M.; Barkmann, J.; Bos, M.M.; Buchori, D.; Erasmi, S.; Faust, H.; Gerold, G.; Glenk, K.; Gradstein, S.R.; et al. Tradeoffs between income, biodiversity, and ecosystem functioning during tropical rainforest conversion and agroforestry intensification. Proc. Natl. Acad. Sci. USA 2007, 104, 4973-4978. [CrossRef] [PubMed]

14. Mukul, S.A.; Rashid, A.Z.M.M.; Khan, N.A. Forest protected area systems and biodiversity conservation in Bangladesh. In Protected Areas: Policies, Management and Future Directions; Mukul, S.A., Rashid, A.Z.M.M., Eds.; Nova Science Publishers: New York, NY, USA, 2017; pp. 157-177.

15. Mukul, S.A. Biodiversity conservation and ecosystem functions of traditional agroforestry systems: Case study from three tribal communities in and around Lawachara National Park. In Forest Conservation in Protected Areas of Bangladesh: Policy and Community Development Perspectives; Chowdhury, M.S.H., Ed.; Springer: Basel, Switzerland, 2014; pp. 171-179.

16. Mukul, S.A. The role of traditional forest practices in enhanced conservation and improved livelihoods of indigenous communities: Case study from Lawachara National Park, Bangladesh. In Proceedings of the 1st International Conference on Forest Related Traditional Knowledge and Culture in Asia, Seoul, Korea, 5-10 October 2008; pp. 24-28.

17. Mukul, S.A. Ecological Trade-Offs between Agroforestry Land-Use, Biodiversity Conservation and Management Intensification, Case Study from in and Around Lawachara National Park, Moulvibazar, Bangladesh. Master's Thesis, Shahjalal University of Science and Technology, Sylhet, Bangladesh, 2009.

18. Mukul, S.A.; Tito, M.R.; Munim, S.A. Can homegardens help save forests in Bangladesh? Domestic biomass fuel consumption patterns and implications for forest conservation in south-central Bangladesh. Int. J. Res. Land-Use Sustain. 2014, 1, 18-25.

19. Kabir, M.E.; Webb, E.L. Can homegardens conserve biodiversity in Bangladesh? Biotropica 2008, 40, 95-103. [CrossRef]

20. Alam, M.K.; Ahmed, F.U.; Ruhul-Amin, S.M. (Eds.) Agroforestry: Bangladesh Perspective; Bangladesh Agricultural Research Council: Dhaka, Bangladesh, 2007.

21. Saha, N.; Azam, M.A. The indigenous hill-farming system of Khasia tribes in Moulvibazar district of Bangladesh: Status and impacts. Small-Scale For. Econ. Manag. Policy 2004, 3, 273-281.

22. Khan, N.A.; Khisa, S.K. Sustainable land management with rubber-based agroforestry: A Bangladeshi example of uplands community development. Sustain. Dev. 2000, 8, 1-10. [CrossRef]

23. Sohel, M.S.I.; Mukul, S.A.; Burkhard, B. Landscape's capacities to supply ecosystem services in Bangladesh: A mapping assessment for Lawachara National Park. Ecosyst. Serv. 2015, 12, 128-135. [CrossRef]

24. MacKinnon, J.R. Protected Areas Systems: Review of the Indo-Malayan Realm; The Asian Bureau for Conservation Limited: Canterbury, UK, 1997.

25. Mukul, S.A.; Herbohn, J.; Rashid, A.Z.M.M.; Uddin, M.B. Comparing the effectiveness of forest law enforcement and economic incentive to prevent illegal logging in Bangladesh. Int. For. Rev. 2014, 16, 363-375. [CrossRef]

26. Pavel, M.A.A.; Mukul, S.A.; Uddin, M.B.; Harada, K.; Khan, M.A.S.A. Effects of stand characteristics on tree species richness in and around a conservation area of northeast Bangladesh. J. Mt. Sci. 2016, 13, 1085-1095. [CrossRef]

27. Mukul, S.A.; Herbohn, J. The impacts of shifting cultivation on secondary forests dynamics in tropics: A synthesis of the key findings and spatio temporal distribution of research. Environ. Sci. Policy 2016, 55, 167-177. [CrossRef]

28. Dey, T.K. Useful Plants of Bangladesh; Add Communication: Chittagong, Bangladesh, 2006. (In Bengali)

29. Das, D.K.; Alam, M.K. Trees of Bangladesh. In Bangladesh Forest Research Institute; Bangladesh Forest Research Institute (BFRI): Chittagong, Bangladesh, 2001.

30. Carrillo, E.; Wong, G.; Cuarón, A.D. Monitoring mammal populations in Costa Rican protected areas under different hunting restrictions. Conserv. Biol. 2000, 14, 1580-1591. [CrossRef]

31. Magurran, A.E. Measuring Biological Diversity; Blackwell Publishing Company: Oxford, UK, 2004. 
32. R Development Core Team. R: A Language and Environment for Statistical Computing; R Foundation for Statistical Computing: Vienna, Austria, 2015.

33. Gibson, L.; Lee, T.M.; Koh, L.P.; Brook, B.W.; Gardner, T.A.; Barlow, J.; Peres, C.A.; Bradshaw, C.J.A.; Laurance, W.F.; Lovejoy, T.E.; et al. Primary forests are irreplaceable for sustaining tropical biodiversity. Nature 2011, 478, 378-381. [CrossRef] [PubMed]

34. DeFries, R.S.; Foley, J.A.; Asner, G.P. Land-use choices: Balancing human needs and ecosystem function. Front. Ecol. Environ. 2004, 2, 249-257. [CrossRef]

35. Harvey, C.A.; Komar, O.; Chazdon, R.; Ferguson, B.G.; Finegan, B.; Griffith, D.M.; Martinez-Ramos, M.; Morales, H.; Nigh, R.; Soto-Pinto, L.; et al. Integrating agricultural landscapes with biodiversity conservation in the Mesoamerican hotspot. Conserv. Biol. 2008, 22, 8-15. [CrossRef] [PubMed]

36. Green, R.E.; Cornell, S.J.; Scharlemann, J.P.W.; Balmford, A. Farming and the fate of wild nature. Science 2005, 307, 550-555. [CrossRef] [PubMed]

37. Moguel, P.; Toledo, V.M. Biodiversity conservation in traditional coffee systems of Mexico. Conserv. Biol. 1999, 13, 11-21. [CrossRef]

38. Mukul, S.A.; Uddin, M.B.; Rashid, A.Z.M.M.; Fox, J. Integrating livelihoods and conservation in protected areas: Understanding role and stakeholders' views on the prospects of non-timber forest products, A Bangladesh case study. Int. J. Sustain. Dev. World Ecol. 2010, 17, 180-188. [CrossRef]

39. Saha, N.; Azam, M.A. Betel leaf based forest farming by khasia tribes: A sustainable system of forest management in Moulvibazar district, Bangladesh. For. Trees Livelihoods 2005, 5, 275-290. [CrossRef]

40. Rahman, S.A.; Sunderland, T.; Kshatriya, M.; Roshetko, J.M.; Pagella, T.; Healey, J.R. Towards productive landscapes: Trade-offs in tree-cover and income across a matrix of smallholder agricultural land-use systems. Land Use Policy 2016, 58, 152-164. [CrossRef]

41. Clough, Y.; Krishna, V.V.; Corre, M.D.; Darras, K.; Denmead, L.H.; Meijide, A.; Moser, S.; Musshoff, O.; Steinebach, S.; Veldkamp, E.; et al. Land-use choices follow profitability at the expense of ecological functions in Indonesian smallholder landscapes. Nat. Commun. 2016, 7, 13137. [CrossRef] [PubMed]

42. Mukul, S.A.; Rashid, A.Z.M.M.; Uddin, M.B. The role of spiritual beliefs in conserving wildlife species in religious shrines of Bangladesh. Biodiversity 2012, 13, 108-114. [CrossRef]

43. Uddin, M.B.; Steinbauer, M.J.; Jentsch, A.; Mukul, S.A.; Beierkuhnlein, C. Do environmental attributes, disturbances, and protection regimes determine the distribution of exotic plant species in Bangladesh forest ecosystem? For. Ecol. Manag. 2013, 303, 72-80. [CrossRef]

44. Mukul, S.A.; Biswas, S.R.; Rashid, A.Z.M.M.; Miah, M.D.; Kabir, M.E.; Uddin, M.B.; Alamgir, M.; Khan, N.A.; Sohel, M.S.I.; Chowdhury, M.S.H.; et al. A new estimate of carbon for Bangladesh forest ecosystems with their spatial distribution and REDD+ implications. Int. J. Res. Land-Use Sustain. 2014, 1, 33-41. 